\title{
P05.36. How do lay people conceptualise and reason about the use of placebos in healthcare?
}

\author{
F Bishop $^{1 *}$, A Adams $^{2}$, E Aizlewood ${ }^{1}$, G Lewith $^{1}$ \\ From International Research Congress on Integrative Medicine and Health 2012 \\ Portland, Oregon, USA. 15-18 May 2012
}

\section{Purpose}

Despite the prevalence and ethically contentious nature of the use of placebos in clinical practice and clinical trials, few studies have explored the perspectives of the general public. Our aim was to identify how lay people conceptualise and reason around the use of placebos in healthcare.

\section{Methods}

Eleven focus groups were held with adult volunteers. Participants were purposefully recruited from rural and urban areas in the Midlands and South of England. They came from a range of walks of life, including students, professionals, home-makers, and retired people. Inductive thematic analysis was facilitated by Atlas.ti.

\section{Results}

All participants recognised the term 'placebo' and exhibited diverse opinions as to how the placebo effect works and whether the placebo effect even exists. Honest doctorpatient communication was highly valued by participants, who typically saw placebo prescriptions as deceitful and therefore wrong. However, they also expressed the belief that that deception is necessary for the patient to experience potentially beneficial placebo effects. A pragmatic orientation was exhibited, wherein participants argued that if a placebo "works" then it is acceptable for a doctor to prescribe it. Placebos were considered more acceptable in certain circumstances, including self-limiting illness (e.g. common cold) and clinical trials (compared to clinical practice).

\section{Conclusion}

Both a pragmatic orientation and an understanding of mind-body healing mechanisms seem to facilitate greater

${ }^{1}$ University of Southampton, Southampton, United Kingdom

Full list of author information is available at the end of the article acceptance of placebos in medical research and clinical practice. Seeing deception as necessary to elicit placebo effects seems to prompt ethical concerns about the use of placebo in clinical practice. The views of the general public should be taken into account when researchers and doctors consider using placebos; these findings could be used to inform the development of more acceptable practices related to the use of placebos.

\section{Author details}

${ }^{1}$ University of Southampton, Southampton, United Kingdom. ${ }^{2}$ Northern Arizona University, Flagstaff, USA.

Published: 12 June 2012

doi:10.1186/1472-6882-12-S1-P396

Cite this article as: Bishop et al:: P05.36. How do lay people

conceptualise and reason about the use of placebos in healthcare? BMC Complementary and Alternative Medicine 2012 12(Suppl 1):P396.

Submit your next manuscript to BioMed Central and take full advantage of:

- Convenient online submission

- Thorough peer review

- No space constraints or color figure charges

- Immediate publication on acceptance

- Inclusion in PubMed, CAS, Scopus and Google Scholar

- Research which is freely available for redistribution
C Biomed Central

○ 2012 Bishop et al; licensee BioMed Central Ltd. This is an Open Access article distributed under the terms of the Creative Commons Attribution License (http://creativecommons.org/licenses/by/2.0), which permits unrestricted use, distribution, and reproduction in any medium, provided the original work is properly cited. 